\title{
APLIKASI MONITORING AKTIVITAS SALES DALAM PENCAPAIAN TARGET PENJUALAN DI DIVISI CONSUMER GOODS
}

\section{Software Monitoring Activities Sales in Achievement of Sales Target on Consumer Goods Division}

\author{
I Ketut Sudaryana ${ }^{1)}$ \\ ${ }^{1)}$ Teknik Informatika, STMIK Widuri \\ Diterima 06 December 2017 / Disetujui 31 January 2018
}

\begin{abstract}
Internet technology is an integral part of our daily life. All people in the world can not be separated from the reach of internet technology. In contrast to the limitations of telecommunications technology that make communication expensive, only very few people can communicate. But with such a rapid progress of Telecommunications and Informatics Technology to communicate from anywhereis not a difficult and expensive thing. And the answer is internet. The Internet makes easier for every person in the world to interact with each other. Any information can be accessed quickly. New communities in the internet world that many emerging, almost all the communities use the Internet as a media campaign by utilizing the network. On the other hand the internet helps people in the world access their source of information they need. People no longer have to be in office and dealing with computers to be able to conduct business activities. With more access to internet services people can perform activities at high mobility without having to go to specific places. With the increasing number of internet access services, the authors deem it necessary to build a system that can help business operations activities on the consumer goods division for sales activity management in assisting company sales staff in doing monitor sales activities that focus on marketing.
\end{abstract}

Keywords: Techology, Internet, Aktifitas Sales, Consumer Goods

\begin{abstract}
ABSTRAK
Teknologi Internet merupakan bagian yang sudah tidak terpisahkan dalam kehidupan kita sehari. Semua orang di belahan bumi manapun tidak terlepas dari jangkauan teknologi internet. Berbeda ketika keterbatasan teknologi telekomunikasi yang membuat komunikasi menjadi barang mahal, sangat sedikit sedikit orang yang dapat berkomuniksi. Tetapi dengan begitu pesat dan hampir meratanya kemajuan Teknologi Telekomunikasi dan Informatika untuk berkomunikasi dari belahan manapun bukan merupakan hal yang sulit dan mahal. Salah satu jawaban ialah pemanfaatan internet. Dengan adanya Internet semakin mudah setiap orang dibelahan bumi manapun untuk berinteraksi satu sama lainnya. Informasi apapun bisa diakses dengan cepat. Komunitas-komunitas di dunia internet yang pun banyak bermunculan. Tidak sedikit yang memanfaatkan internet sebagai media promosi dengan memanfaatkan jaringan komunitas-komunitas tersebut. Disisi lain internet membantu orang dibelahan dunia manapun mengakses sumber informasi yang mereka butuhkan. Orang tidak lagi harus berada dikantor dan berhadapan dengan komputer untuk bisa melakukan kegiatan-kegiatan businessnya. Dengan semakin banyak akses layanan internet orang dapat melakukan kegiatan-kegiatan di dengan mobilitas tinggi tanpa harus tergantung tempat. Dengan semakin banyaknya layanan akses internet, penulis memandang perlu membangun suatu sistem yang dapat membantu kegiatan operasional bisnis perusahan di divisi consumer goods untuk manajemen aktivitas sales dalam membantu staff sales perusahaan dalam melakukan memonitoring berbagai aktifitas sales yang fokus pada marketing

Kata Kunci: Techology, Internet, Sales Activity, Consumer Goods
\end{abstract}




\section{PENDAHULUAN}

Teknologi Internet merupakan bagian yang sudah tidak terpisahkan dalam kehidupan kita sehari. Semua oarang di belahan bumi manapun tidak terlepas dari jangkauan teknologi internet. Berbeda ketika keterbatasan teknologi telekomunikasi yang membuat komunikasi menjadi barang mahal, sangat sedikit sedikit orang yang dapat berkomuniksi. Tetapi dengan begitu pesat dan hampir meratanya kemajuan Teknologi Telekomunikasi dan Informatika untuk berkomunikasi dari belahan manapun bukan merupakan hal yang sulit dan mahal. Salah satu jawaban ialah pemanfaatan internet. Teknologi informasi merupakan bagian penting dari kehidupan manusia sekarang ini. Teknologi berperan penting dalam berbagai bidang untuk menunjang setiap aktivitas kehidupan manusia serta mampu mempermudah setiap keperluan hidup manusia sehari-hari (Santoso, 2015).

Dengan adanya Internet semakin mudah setiap orang dibelahan bumi manapun untuk berinteraksi satu sama lainnya. Informasi apapun bisa diakses dengan cepat. Komunitas-komunitas di dunia internet yang pun banyak bermunculan. Tidak sedikit yang memanfaatkan internet sebagai media promosi dengan memanfaatkan jaringan komunitas-komunitas tersebut. Kehadiran internet telah menjadi bagian yang tidak terpisahkan dalam kehidupan manusia pada abad ke-21. Kehadirannya juga dinilai cukup berpengaruh terhadap perkembangan dunia bisnis. Dikarenakan internet dapat membuat komunikasi dan pertukaran informasi pada kegiatan bisnis menjadi semakin mudah (Kusumawijaya dan Karyati, 2016). Produk dan jasa yang dihasilkan memberikan manfaat seperti informasi mudah dan cepat didapatkan serta mudah dibagi. Salah satu produk dan jasa yang dihasilkan adalah website (Monalisa, 2016). Website merupakan salah satu bentuk media masa yang dipublikasi melalui jaringan internet yang dapat diakses dimanapun dan kapanpun. Website memiliki beberapa jenis dengan fungsi yang berbeda-beda (Baiti, Suprapto dan Rachmadi, 2017).

Dengan semakin banyaknya layanan akses internet, penulis memandang perlu membangun suatu sistem yang dapat membantu kegiatan operasional business perusahan dimana penulis bekerja yang bergerak dibidang penyediaan peralatan teknik industri dan permesinan untuk Manajemen Aktivitas Sales dalam membantu staf sales perusahaan kami melakukan memonitoring berbagai aktifitas sales yang titik berat pada marketing.

Tenaga penjualan sebagai salesforce dalam menghasilkan keuntungan merupakan hal yang perlu dicermati untuk mengkomunikasikan antara produk dengan konsumen hal ini sesuai dengan pengertian yang diberikan. Kesuksesan perusahaan dalam mengelola segala sumber daya yang berkaitan dengan tenaga penjualan akan mendukung keberhasilan perusahaan itu dalam mencapai tujuannya (Kusmanto dan Sampurno, 2006). Salah satu tujuan utama dari pengaturan tenaga penjual adalah mencapai penjualan produk berkelanjutan yang pada akhirnya untuk mempertahankan penjualan dalam jangka panjang sesuai dengan tujuan perusahaan. Noor, N. et. al (2001) menyatakan bahwa ketrampilan, perilaku, faktor-faktor personal dan role perception memberikan pengaruh yang signifikan terhadap kinerja tenaga penjualan. Menurut Anderson dan Oliver, 1987 berpendapat bahwa, sistem kontrol tenaga penjualan merupakan seperangkat alat untuk mencapai tujuan melalui memonitor dan mengevaluasi kemajuan, memberi umpan balik, memperkuat tenaga penjualan sebagai basis dari kinerja penjualan.

Sales perlu mencatat semua kegiatan yang sudah mereka lakukan untuk bisa menentukan tindak lanjut apa yang harus dilakukan terhadap customer yang memiliki prospek. Untuk itu mereka harus dibekali suatu sistem yang dapat diakses mereka tanpa dibatasi oleh waktu dan tempat untuk bisa menindak lanjuti setiap customer yang 
potensial dengan cepat dan tepat. Dengan ada aplikasi ini akan berdampak meningkatkan optimalnya aktivitas setiap sales dalam menindaklanjuti customer yang memiliki prospek. Urgency dari paper ini adalah perlu membuat sebuah sistem berbasis web yang dapat diakses dari lokasi manapun dengan memanfaatkan internet. Sistem ini nanti diharapkan dapat merekam setiap kegiatan staff sales dalam melakukan aktifitasnya, disamping itu juga sebagai sumber informasi yang dapat di-sharing atau dibagikan, yang pada akhir akan semakin meningkat produktifitas para staff sales. Diharapkan dengan aplikasi ini dapat meningkatkan optimalnya aktivitas setiap sales dalam menindaklanjuti customer yang memiliki prospek.

\section{METODOLOGI PENELITIAN}

Metode System Development Life Cycle (SDLC) adalah metode yang menggunakan pendekatan sistem yang disebut pendekatan air terjun (waterfall approach) dimana setiap tahapan sistem akan dikerjakan secara berurut menurun dari perencanaan, analisa, desain, implementasi, dan perawatan. Tahapan dalam SDLC yang dikemukakan oleh para ahli memiliki perbedaan yang beragam sesuai dengan pemahamannya masing masing, sehingga tahapan yang dilakukan oleh peneliti memiliki perbedaan serupa dengan pemahaman yang kami miliki. Oleh karena itu, peneliti akan memberikan penjelasan tahapan yang telah dibuat, yaitu: (Andry dan Reinaldo, 2017)

1. User Requirement, mengumpulkan beberapa informasi mengenai kebutuhan user yang berguna untuk mengetahui dan membantu perancangan terhadap aplikasi yang akan dibuat. Informasi tersebut dapat berupa kebutuhan fungsi dalam aplikasi, masalah dan solusi yang dapat dicapai dari perancangan aplikasi, dan lainnya. Hasil keluaran dari tahap ini dapat berupa Business Requirement Statement.
2. Analysis,memungkinkan untuk membuat gambaran terhadap logika perancangan aplikasi yang diinginkan. Gambaran logika dapat berupa struktur dan berorientasi objek, dimana struktur berarti menggunakan Data Flow Diagram, dan berorientasi objek menggunakan Unified Modeling Language (UML). Peneliti memilih perancangan beorientais objek sehingga hasil keluaran dari tahap ini adalah UML.

3. Design, menjelaskan bagaimana kami membuat gambaran terhadap rancangan aplikasi yang dibuat. Gambaran tersebut dapat berupa User Interface dan desain terhadap database yang akan digunakan dalam aplikasi. Hasil keluaran yang dilakukan oleh peneliti pada tahap ini adalah desain user interface dan desain rancangan database.

4. Coding, tahapan dimana memulai untuk membuat kode pemrograman terhadap pembangunan aplikasi yang telah ditentukan. Hasil keluaran dari tahap ini adalah aplikasi selesai dibuat dan siap untuk dilakukan tahap pengujian.

5. Testing, pengujian dilakukan setelah aplikasi selesai dibuat, dengan metode black box testing. Pengujian dilakukan dengan User Acceptance Testing (UAT) dan Coding Phase Defect, dimana hasil keluaran dari tahap ini adalah UAT dan Coding Phase Defect tersebut. Pengujian dilakukan untuk mengetahui dan mengindentifikasi kesalahan yang mungkin terjadi.

6. Implementasi, tahapan dimana siap memberikan aplikasi dan mengimplementasikannya untuk digunakan kepada user.

\section{HASIL DAN PEMBAHASAN}

Proses penjualan yang terjadi saat ini di PT Kawan Lama Sejahtera adalah sebagai berikut:

1. Terdapat sebanyak 10 tenaga penjualan. 
2. Semua tenaga penjualan dibagi dalam 2 kelompok.

3. Masing-masing kelompok dipimpin oleh satu orang yang menjabat sebagai supervisor.

4. Masing-masing anggota kelompok melaporkan kegiatan hariannya ke supervisor.

5. Masing-masing supervisor melaporkan kegiatan ke Sales Manager per minggu.

6. Semua laporan kegiatan anggota sales berbentuk hardcopy kepada supervisor.

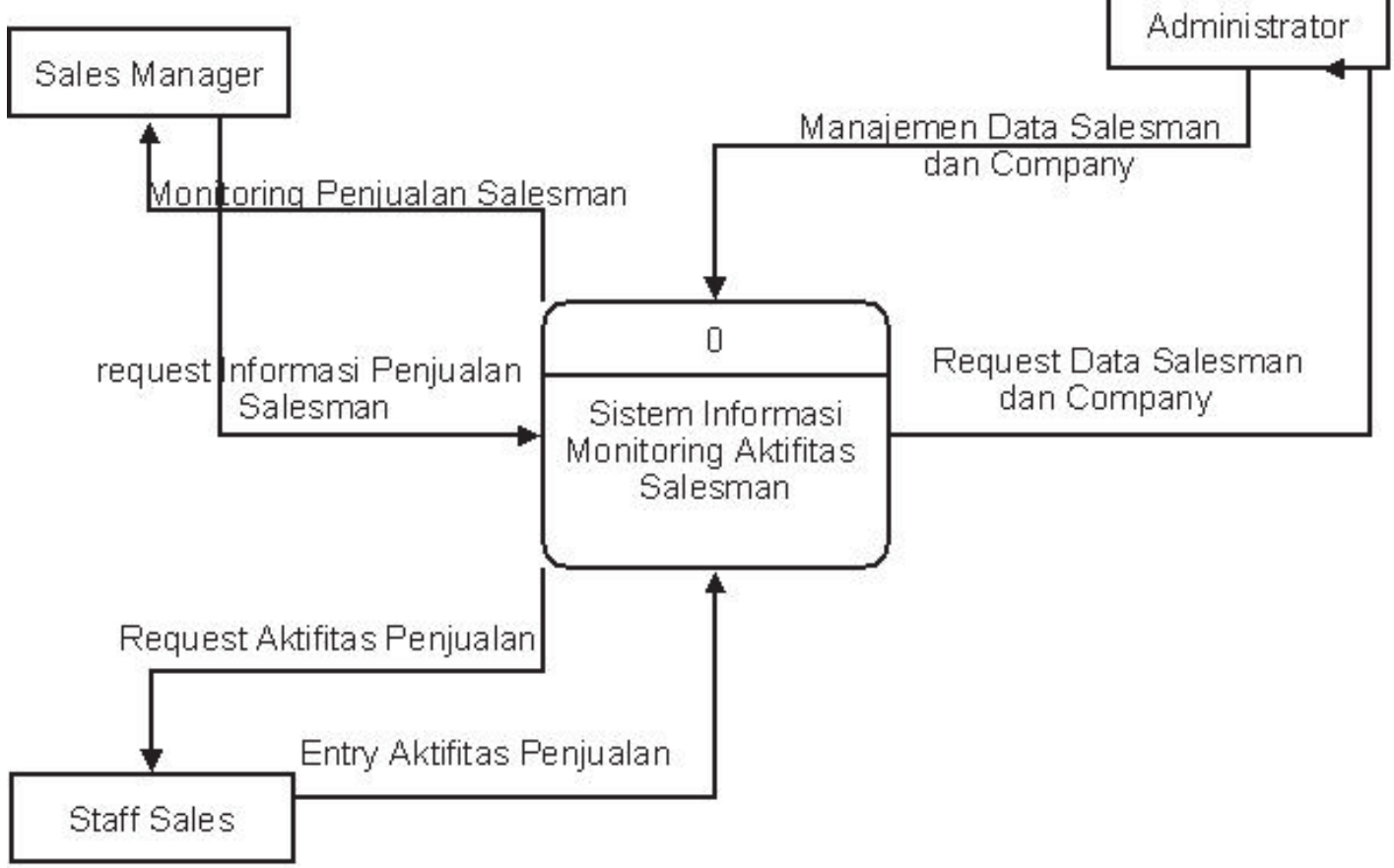

7. Semua laporan Supervisor dalam excel sesuai dengan format yang diberikan Sales Manager.

8. Sales Manager melakukan review terhadap semua kegiatan dari tenaga penjualan dan supervisor penjualan.

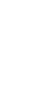




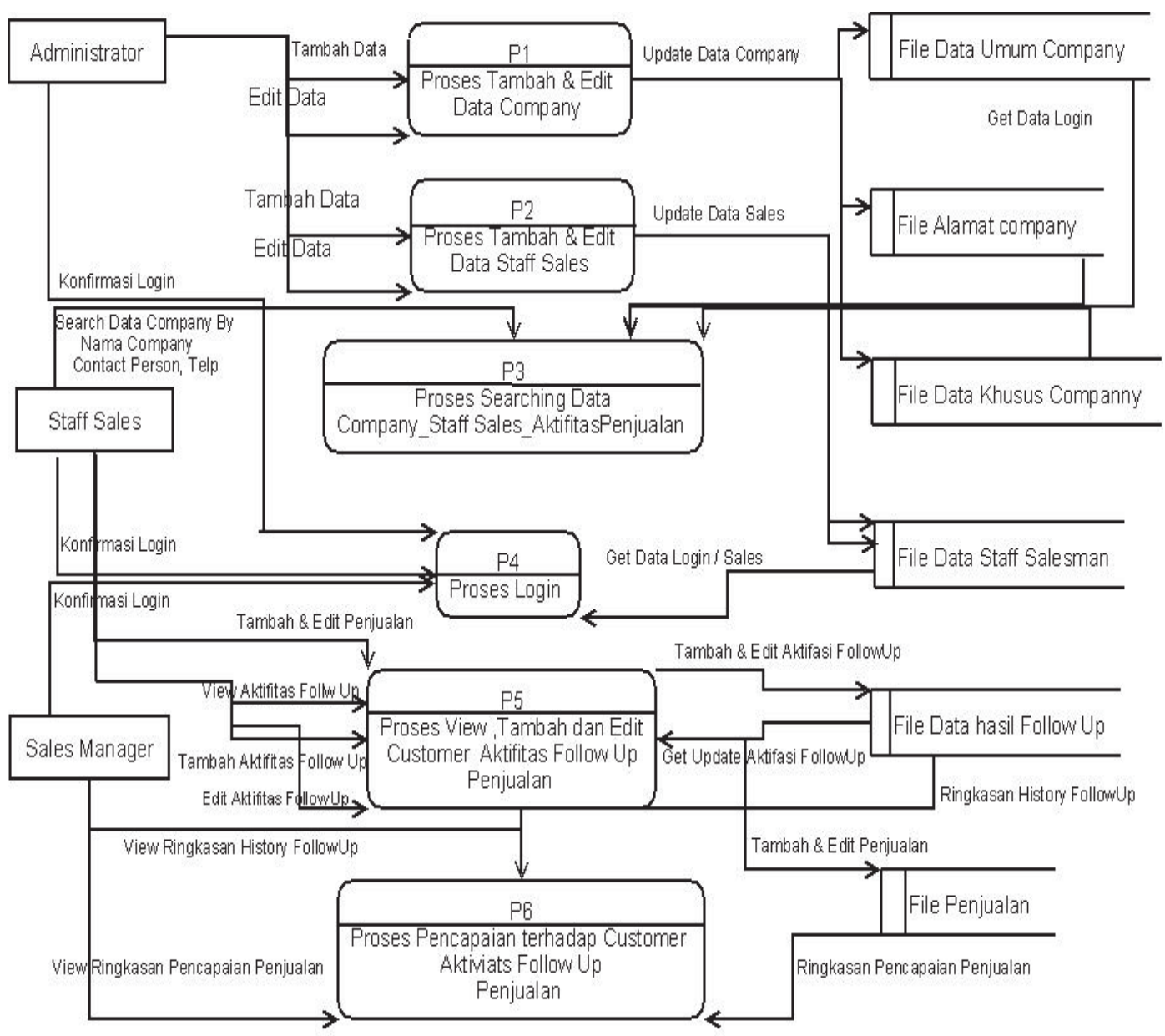

Gambar 2. DFD Level 1 Sistem Monitoring Aktivitas Tenaga Penjualan

Pada DFD level 1 terdapat beberapa proses utama sebagai berikut yaitu:

1. Proses Tambah dan Edit Data Perusahaan Pelanggan.

2. Pada Proses ini, administrator melakukan penambahan dan perubahaan data dari Perusahaan pelanggan. Data Pelanggan terdiri dari 3 kategori yaitu data umum, data alamat dan data spesifik dari perusahaan pelanggan.

3. Proses Tambah dan Edit Data Tenaga Penjualan

4. Pada Proses ini, administrator melakukan penambahan dan perubahaan data dari tenaga penjualan. Tenaga Penjualan mencakup Sales Manager dan staff.
5. Proses Pencarian Searching

6. Pada Proses ini dilakukan pencarian data terkait data perusahaan pelanggan, tenaga penjualan dan aktivitas follow yang dilakukan oleh tenaga penjualan terhadap pelanggan.

7. Proses Login

8. Pada proses diatur autorisasi pengguna dari Sistem Monitoring Aktifitas Tenaga Penjualan untuk dapat menggunakan sistem sesuai dengan wewenang yang sudah diatur yaitu 1 untuk Administrator dan Sales Manager dan 9 untuk staf tenaga penjualan.

9. Proses View, Tambah dan Edit Aktivitas Follow Up 
10. Pada proses ini penambahan dan perubahaan data dari aktifitas follow up yang dilakukan tenaga penjualan terhadap pelanggan. Setiap tenaga penjualan wajib mengisi aktivitas yang mereka lakukan. History dari aktivitas follow tersebut dilakukan terkait pembayaran yang belum lengkap dari pelanggan.

11. Proses View Hasil Pencapaian Penjualan dari Aktivitas Follow
UpPada proses ini akan menampilkan ringkasan seluruh kegiatan yang dilakukan oleh semua tenaga penjualan, yang menggambarkan apakah target penjualan dan aktivitas yang sudah direncanakan dibandingkan dengan pencatatan follow up dan penjualan tercapai atau tidak.

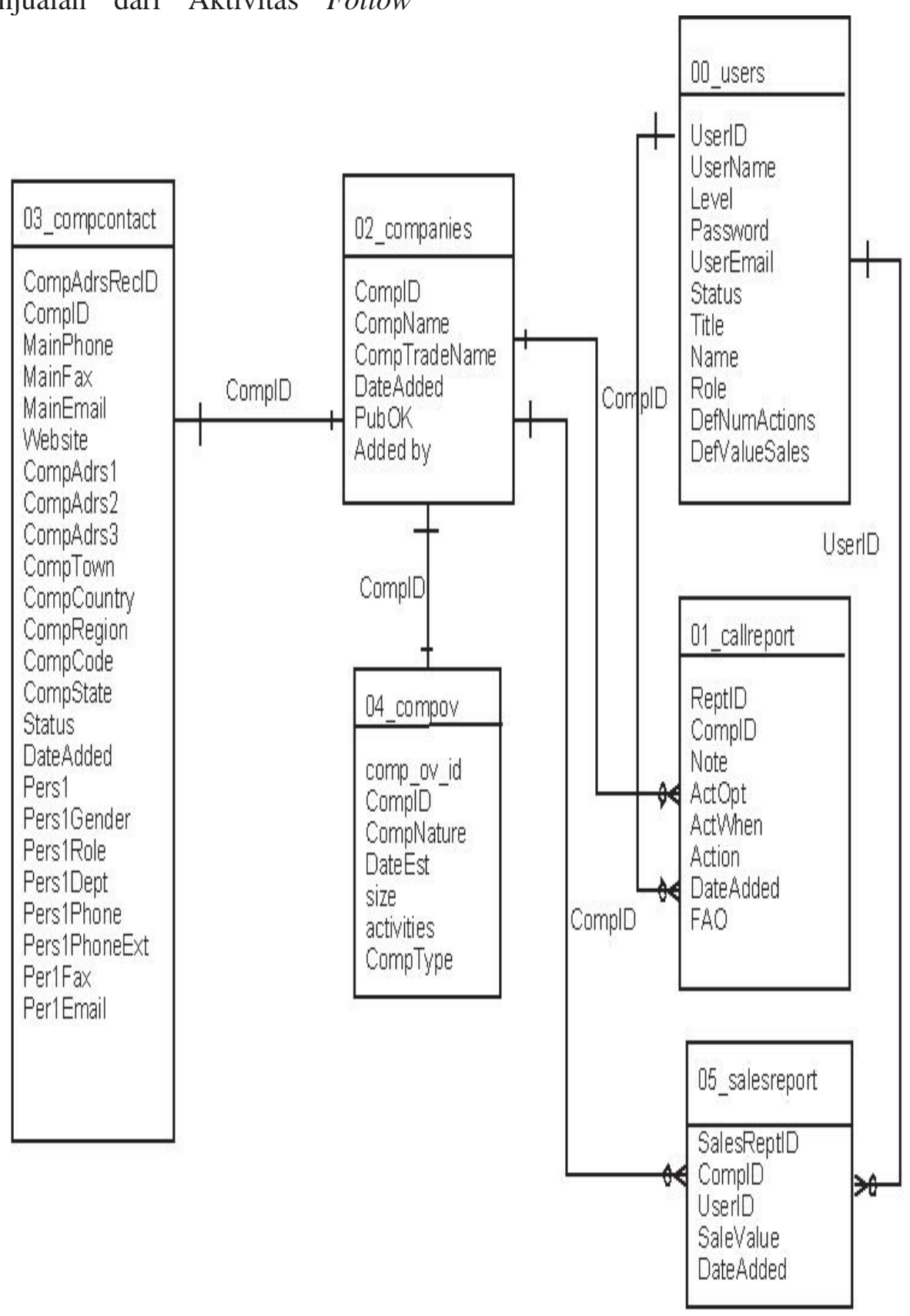


Gambar 3. Conceptual ERD

Dalam ERD, entitas dari Sistem Monitoring Aktifitas Tenaga Penjualan dapat dibagi menjadi 6 entitas yaitu Salesman, Master Data Pelanggan, Master Data Kontak Pelanggan, Master Data Bidang Usaha Pelanggan, Sales History, History Follow Up. ERD konseptual dapat dilihat pada gambar 3, Relasi ERD dapat dijelaskan sebagai berikut:

1. Relasi antara 03_compcontact dengan 02_companies adalah relasi one to one. Relasi ini menunjukkan hubungan antara master data umum perusahaan pelanggan dengan master data kontak perusahaan.

2. Relasi antara 04_compov dengan 02_companies adalah relasi one to one. Relasi ini menunjukkan hubungan master data umum perusahaan pelanggan dengan master data khusus perusahaan pelanggan seperti jumlah pegawai, area bisnis dan tipe bisnis dari perusahaan pelanggan.

3. Relasi antara 02_companies dengan 01_callreport adalah relasi one to many. Relasi ini menunjukkan hubungan antara master data tenaga penjualan dengan kegiatan follow up tenaga penjualan terhadap perusahaan pelanggan terkait penagihan pembayaran.

4. Relasi antara 00_users dengan 05_salesreport adalah relasi one to many.

5. Relasi ini menunjukkan hubungan antara master data tenaga penjualan dengan pembayaran yang sudah dilakukan oleh perusahaan pelanggan

6. Relasi antara 02_companies dengan 05_salesreport adalah relasi one to many.

7. Relasi antara 00_user ke 01_callreport adalah relasi one to many. Relasi ini menunjukkan bahwa setiap staf penjualan mempunyai banyak kegiatan.

\section{Proses Login}

Terdapat 3 kategori user pengguna dari system ini yaitu: Admin, sales manager dan staff sales. Adapun wewenang dari admin dan sales manager adalah sama. Tampilan halaman login adalah sebagai seperti yang tertera pada gambar 4 . 


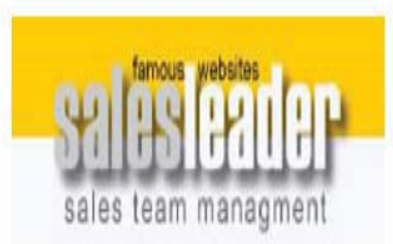

\section{Login Page}

User Name

Password

\section{Log in}

\section{Gambar 4. Halaman Login}

\section{Proses Searching}

Untuk melihat detail informasi dari hasil pencarian dari perusahaan pelanggan berdasarkan kategori yang terdapat pada poin diatas, maka pengguna aplikasi ini dapat cukup mengklik tanda yang terdapat disamping nama perusahaan pelanggan. Adapun tampilan halaman detail dari hasil pencarian adalah seperti yang terdapat pada gambar 5 . 


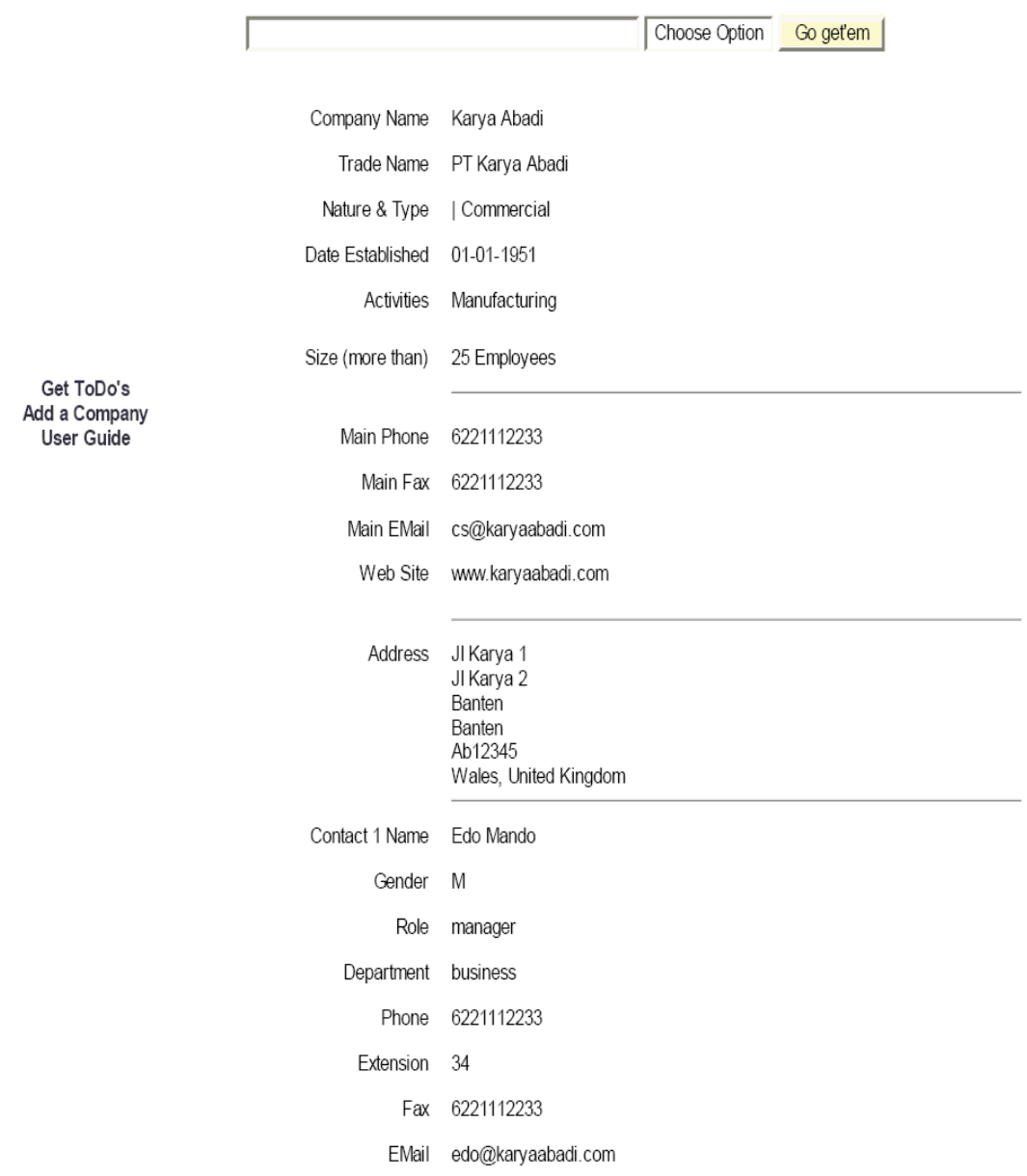

Gambar 5. Detail hasil Pencarian

\section{KESIMPULAN DAN SARAN}

\section{Kesimpulan}

Dari pembahasan pada bab-bab sebelumnya mengenai perancangan dan pembuatan Aplikasi Monitoring Kegiatan Follow Up Tenaga Penjualan dengan menggunakan PHP dan Mysql pada platform windows XP dan maka dapat ditarik kesimpulan bahwa aplikasi ini digunakan untuk melakukan otomatisasi monitoring kegiatan follow up dan penjualan produk dari perusahaan. Aplikasi Monitoring Kegiatan Follow Up Tenaga Penjualan akan melakukan penjadwalan menggunakan algoritma yang ada dalam mencari waktu yang cocok bagi semua peserta untuk memenuhi tujuan dari pengguna. Diharapkan dengan adanya aplikasi ini, dapat membantu pengguna dalam menyelesaikan tugasnya yang berhubungan dengan penjadwalan rapat dengan mudah sehingga dapat meningkatkan produktifitas kerja pengguna.

\section{Saran}

Pengembangan aplikasi ini diharapkan dapat dikembangkan lebih lagi sehingga aplikasi Monitoring Kegiatan Follow Up Tenaga Penjualan ini menjadi lebih kompleks dan lebih baik dalam melakukan penjadwalan rapat.

\section{DAFTAR PUSTAKA}


Anderson, James C. and James A. Narus, 1990, A Model of Distributor Firm and Manufacture Firm Working Partnerships, Journal of Marketing, 54 (Januari), p.42-58.

Baiti, Amirah Al, Suprapto dan Rachmadi, Aditya. 2017. Pengukuran Kualitas Layanan Website Dinas Pendidikan Kota Malang Dengan Menggunakan Metode Webqual 4.0 Dan Ipa.

J.F, Andry dan Reinaldo. 2017. Testing dan Implementasi Aplikasi Parkir di PT ABC Menggunakan Metode Black Box, Prosiding Seminar Nasional Multi Disiplin Ilmu VIII (SENMI) 2017 Universitas Budi Luhur.

Kusmanto dan Sampurno, Joko. 2006. Analisis Faktor-Faktor Yang Mempengaruhi Kinerja Hasil Tenaga Penjualan Dan Hubungannya Terhadap Efektifitas Penjualan Perusahaan (Studi Kasus Pada Bpr Di Eks. Karesidenan Semarang), Jurnal Studi Manajemen \& Organisasi, Volume 3, Nomor 1, Januari, Tahun 2006.
Kusumawijaya, Ike Putri Dan Karyati, Cut Maisyarah. 2016. Pengukuran Kualitas Website Fashion ECommerce Menggunakan Metode Webqual 4.0.

Monalisa, Siti. 2016. Analisis Kualitas Layanan Website Terhadap Kepuasan Mahasiswa Dengan Penerapan Metode Webqual (Studi Kasus : Uin Suska Riau).

Noor, N, Ameen, T.R.M.A, and Wahad, A. 2001. Determinant of Salesperson Performance. Journal Strategy Bisnis, Vol.6, p.67-80.

Santoso, Budi Setiawan. 2015. Analisis Kualitas Website Menggunakan Metode Webqual Dan Importance Performance Analysis (Ipa) Pada Situs Kaskus. 